\title{
Rosuvastatin induces apoptosis in cultured human papillary thyroid cancer cells
}

\author{
N Dilara Zeybek ${ }^{1}$, Nese Ersoz Gulcelik ${ }^{2}$, F Figen Kaymaz ${ }^{1}$, Can Sarisozen ${ }^{4}$, Imran Vural ${ }^{4}$, Ebru Bodur ${ }^{3}$, \\ Hande Canpinar ${ }^{5}$, Aydan Usman ${ }^{2}$ and Esin Asan ${ }^{1}$ \\ Departments of ${ }^{1}$ Histology and Embryology, ${ }^{2}$ Endocrinology and Metabolism and ${ }^{3}$ Medical Biochemistry, Faculty of Medicine, Hacettepe University, Sihhiye, \\ Ankara 06100, Turkey \\ ${ }^{4}$ Department of Pharmaceutical Technology, Faculty of Pharmacy, Hacettepe University, Ankara 06100, Turkey \\ ${ }^{5}$ Department of Basic Oncology, Oncology Institute, Hacettepe University, Ankara 06100, Turkey \\ (Correspondence should be addressed to N D Zeybek; Email: dilaraz@hacettepe.edu.tr)
}

\begin{abstract}
Statins show antiproliferative activity in various cancer cells. The aim of this study was to evaluate the effects of rosuvastatin treatment on papillary thyroid carcinoma. The papillary thyroid carcinoma (B-CPAP) and normal (Nthy-ori 3-1) thyroid cell lines were treated with rosuvastatin at $12 \cdot 5,18 \cdot 5$, $25,50,100$, and $200 \mu \mathrm{M}$ concentrations. After 48 and $72 \mathrm{~h}$ of rosuvastatin treatment, 3-(4,5-dimethylthiazol-2-yl)-2, 5-diphenyl tetrazolium bromide, Ki-67 immunolabeling, FACS analysis, electron microscopy, caspase-3, and terminal deoxynucleotidyl transferase-mediated dUTP nick endlabeling (TUNEL) analysis were performed. Decreased cell viability and G1 phase arrest were detected in papillary thyroid cell line treated with rosuvastatin. Positive immunoreactivity of Ki-67 and dose-dependent increase in S phase on Nthy-ori 3-1 cells were also detected. B-CPAP cells showed intense vacuolisation and autophagosomes with low concentrations

and $48 \mathrm{~h}$ incubations, while Nthy-ori 3-1 cells showed these changes at higher concentrations. A decrease in the percentage of cells showing autophagy was determined with increasing concentrations of rosuvastatin in B-CPAP cells. Rosuvastatin treatment also caused a dose- and time-dependent increase in caspase- 3 activity and apoptotic index by TUNEL assay in B-CPAP cells compared with the Nthy-ori 3-1 cells. Apoptotic cells with nuclear condensation and fragmentation were observed in B-CPAP cell line. Rosuvastatin induced autophagic changes in B-CPAP papillary thyroid cancer cells in lower doses and caused a shift from autophagy to apoptosis. Rosuvastatin may be an alternative treatment for refractory papillary thyroid cancer. Further in vivo studies are necessary to clarify the effects of rosuvastatin in papillary thyroid carcinoma and the clinical implications of rosuvastatin treatment. Journal of Endocrinology (2011) 210, 105-115
\end{abstract}

\section{Introduction}

Statins are the competitive inhibitors of 3-hydroxy-3methylglutaryl CoA (HMG-CoA) reductase and are routinely used for the treatment of hypercholesterolemia. The enzyme HMG-CoA reductase catalyses the conversion of HMG-CoA to mevalonate (Goldstein \& Brown 1990). Inhibition of mevalonate by statins leads to a decrease in both cholesterol and important intermediate metabolites, such as the isoprenoids, farnesyl pyrophosphate, and geranylgeranyl pyrophosphate, which are involved in the post-translational prenylation of several proteins (i.e. Ras, Rho, and Rac) that modulate a variety of cellular processes, including cellular signaling, differentiation, proliferation, and apoptosis (Alegret \& Silvestre 2006, Katsiki et al. 2009).

HMG-CoA reductase inhibition displays immunomodulatory, anti-inflammatory and anti-oxidant activity, which is unrelated to the effects on lipid metabolism (Bifulco 2008). A number of studies demonstrated antineoplastic effects of statins (Campbell et al. 2006, Sivaprasad et al. 2006, Lin et al. 2008). The antiproliferative effects of statins were demonstrated in in vitro studies on hepatocellular carcinoma (Kawata et al. 1994), lung (Hawk et al. 1996), breast (Campbell et al. 2006), and pancreatic cancer cells (Gbelcová et al. 2008). These effects appear to be generated either via effects on cell cycle and induction of growth suppression or via induction of apoptosis of malignant cells (Sassano \& Platanias 2008).

There are limited studies on the antiproliferative effect of statins on thyroid cells, which were performed on proliferating rat thyroid cells or anaplastic thyroid cancer cells. Bifulco et al. (1999) showed the antiproliferative and/or proapoptotic activity of lovastatin in proliferating rat thyroid cells. Zhong et al. (2003) demonstrated the effectiveness of lovastatin in the treatment of anaplastic thyroid cancer in in vitro studies.

To our knowledge, there is no study on the effect of statin treatment on differentiated thyroid cancer cells. Moreover, the effect of statin treatment on thyroid growth is of clinical interest. Recently, Cappelli et al. (2008) reported decreased 
incidence of nodules in patients on statin therapy. In this study, the effect of rosuvastatin on papillary thyroid carcinoma cell line (B-CPAP) was investigated.

\section{Materials and Methods}

\section{Cell line and cell culture}

The human papillary thyroid cancer cell line B-CPAP was purchased from Deutsche Sammlung von Mikroorganismen und Zellkulturen (DSMZ, Braunschweig, Germany). The normal thyroid follicular epithelial cell line Nthy-ori 3-1 was obtained from European Collection of Cell Cultures (ECACC, Wiltshire, UK). Both cell lines were cultured in RPMI 1640 (Sigma Chemical Co.) supplemented with 10\% heat-inactivated FCS, $2 \mathrm{mM}$ L-glutamine and 1\% penicillin/streptomycin under standard cell culture conditions $\left(37^{\circ} \mathrm{C}\right.$, $100 \%$ humidity and $5 \% \mathrm{CO}_{2}$ ). Both cell lines were treated with rosuvastatin (Lot no. 294201308, Abdi Ibrahim Ilac, Istanbul, Turkey) at 12.5, 18.5, 25, 50, 100, and $200 \mu \mathrm{M}$ concentrations for 48 and $72 \mathrm{~h}$.

\section{Determination of cell viability}

The cytotoxic effects and cell viability of rosuvastatin were determined by MTT assay. This method is based on the reduction of 3-(4,5-dimethylthiazol-2-yl)-2,5-diphenyl tetrazolium bromide to formazan. Viable cells convert yellowcolored MTT to violet-colored formazan crystals using the mitochondrial succinate dehydrogenase, which is a part of the respiratory chain. Therefore, cell viability can be determined by measuring the optical density of the formazan product with regard to cellular respiration and metabolic rate. The 3-(4,5-dimethylthiazol-2-yl)-2,5-diphenyl tetrazolium bromide dye solution (MTT; Applichem, Darmstadt, Germany) was prepared as $5 \mathrm{mg} / \mathrm{ml}$ in PBS at $37^{\circ} \mathrm{C}$. Nthyori 3-1 and B-CPAP thyroid cell lines were plated $10 \times 10^{3}$ cells/well in 96-well plates in $100 \mu \mathrm{l}$ of culture medium. When the cultures were at sub-confluence the medium was removed. The cell monolayers were washed with PBS and exposed to $100 \mu \mathrm{l}$ of culture medium (untreated) and to different concentrations of rosuvastatin $(12 \cdot 5,25,50,100$, and $200 \mu \mathrm{M}$ ) for 48 and $72 \mathrm{~h}$. At the end of the treatment, $25 \mu \mathrm{l}$ of MTT dye was added to each well and incubated for $4 \mathrm{~h}$ at $37^{\circ} \mathrm{C}$. After incubation, the formazan product was solubilised in $23 \%$ SDS in a solution of $45 \% \mathrm{~N}, \mathrm{~N}$-dimethylformamide and the plate was placed on a shaker for $2 \mathrm{~min}$. The amount of formazan crystals reflecting cellular growth and viability was determined quantitatively by absorbance measurements at $570 \mathrm{~nm}$ using a microplate reader (Spectramax Plus, Moleculer Devices, Sunnyvale, CA, USA). Three replicates were performed in each test. Reported values are the mean of two measurements and are expressed as percent viability with respect to untreated control.

\section{Analysis of Ki-67 immunoreactivity}

The immunoreactivity of Ki-67 was determined by using an indirect immunoperoxidase method. B-CPAP and Nthy-ori 3-1 thyroid cells were grown on coverslips for immunohistochemical evaluation and incubated with rosuvastatin for 48 and $72 \mathrm{~h}$. Cells on coverslips were fixed with $2 \%$ buffered paraformaldehyde solution for $5 \mathrm{~min}$ and washed with PBS. After treating with $2.5 \% \mathrm{BSA}$ for $1 \mathrm{~h}$, the cells were incubated with anti-mouse Ki-67 primary antibody (Invitrogen, Cat no.: $08-1156)$ at a final dilution of 1:200 for $1 \mathrm{~h}$ at room temperature in a humidified chamber. After removal of primary antibodies, the coverslips were washed three times with PBS and incubated with a 1:200 dilution of goat-anti mouse IgG (Cat no. 31160, Pierce Inc., Rockford, IL, USA) in PBS containing 0.2\% BSA (Sigma, Cat no.: A-7034) and 1\% normal human serum for half an hour at room temperature. The coverslips were washed with PBS and incubated with diaminobenzidine (Cat no. K3468, Dako, Glostrup, Denmark) for $5 \mathrm{~min}$ and counterstained with hematoxylin. The control staining was performed by omitting the primary antibody step.

The samples were then examined and photographed by using a light microscope (Leica DM6000B, Wetzlar, Germany) with a DC490 digital camera (Leica). The Ki-67 immunopositive cells were counted on four randomly selected areas under a light microscope ( $20 \times$ magnification) by two investigators blinded to the experiments. The mean value of the scores provided by the two investigators was used for graphical and statistical calculations.

\section{Analysis of cell cycle phase}

Changes in cell cycle distribution were analysed with the flow cytometry method. B-CPAP and Nthy-ori 3-1 cells were incubated in the absence (control cells) or presence of rosuvastatin for 48 and $72 \mathrm{~h}$. Both adherent and floating cells were collected and fixed in cold $80 \%$ ethanol at $+4{ }^{\circ} \mathrm{C}$ overnight. Cells were then centrifuged, washed with $1 \mathrm{ml}$ PBS and resuspended in $2 \mathrm{ml}$ PBS. To a $2 \mathrm{ml}$ cell suspension, 30 units of DNase-free RNase were added and then $100 \mu \mathrm{l}$ propidium iodide (PI; $50 \mu \mathrm{g} / \mathrm{ml}$ ) were added. After a gentle mixing, the resuspended cells were incubated under dark conditions at $37^{\circ} \mathrm{C}$ for $1 \mathrm{~h}$ and covered until used. The PI fluorescence of the cells were analysed by flow cytometry (EPICS XLMCL, Beckman Coulter Inc., Brea, CA, USA). MultiCycle software from Phoenix Flow Systems (San Diego, CA, USA) was used to deconvolute the cellular DNA content histograms to obtain quantisation of the percentage of cells in the respective phases (G1, S, and G2/M) of the cell cycle.

\section{Electron microscopic analysis}

B-CPAP and Nthy-ori 3-1 thyroid cells were grown in flasks for ultrastructural examination and incubated with 12.5 , $18 \cdot 5,25,50,100$, and $200 \mu \mathrm{M}$ concentrations of rosuvastatin for 48 and $72 \mathrm{~h}$. Both adherent and floating cells were 
collected and electron microscopic analysis was performed. Briefly, cells were fixed in $2 \cdot 5 \%$ glutaraldehyde solution in phosphate buffer, $\mathrm{pH} 7 \cdot 4$, for $4 \mathrm{~h}$ and post-fixed for $1 \mathrm{~h}$ in $1 \%$ osmium tetroxide in $0 \cdot 1 \mathrm{M}$ phosphate buffer. After washing in phosphate buffer, they were dehydrated in a graded series of ethanol to absolute ethanol, treated with propylene oxide and embedded in Araldite/Epon812 (Cat no.: 13940, EMS, Hatfield, PA, USA). After heat polymerisation, sections were cut using a microtome. Semi-thin sections were stained with methylene blue-azure II and examined using a light microscope (Leica) with a DC490 digital camera (Leica). Ultrathin sections (Leica ultracut R) were double-stained with uranyl acetate and lead citrate (Leica EM AC20). These sections were examined in JEOL-JEM 1400 electron microscope and photographed by CCD camera (Gatan Inc., Pleasanton, CA, USA). Cells were classified into the following types: 1) cells without significant morphological change 2) apoptotic cells with condensed, fragmented dark nuclei, apoptotic bodies 3) autophagic cells containing five or more vacuoles and/or multiple autophagic structures. The autophagic and apoptotic cells were counted in randomly chosen fields and data were given as percentages of total cells present.

\section{Terminal deoxynucleotidyl transferase-mediated dUTP nick end-labeling assay}

Apoptosis was determined by enzymatic labeling of DNA strand breaks using terminal deoxynucleotidyl transferasemediated dUTP nick end-labeling (TUNEL) method with Cell Death Detection kit (Roche) according to manufacturers' instructions. Briefly, thyroid cells grown on sterile Lab-Tec chamber slides were incubated with increasing concentrations of rosuvastatin for 48 and $72 \mathrm{~h}$. After fixation with $4 \%$ paraformaldehyde for $30 \mathrm{~min}$, the slides were incubated with the permeabilisation solution $(0 \cdot 1 \%$ Triton $\mathrm{X}-100$ in $0 \cdot 1 \%$ sodium citrate) for $8 \mathrm{~min}$ at $4{ }^{\circ} \mathrm{C}$. After washing twice with PBS for $5 \mathrm{~min}$, the labeling reaction was performed using terminal deoxynucleotidyl transferase end-labeling cocktail for each sample, except for negative control, in which reagent without enzyme was added and incubated for $1 \mathrm{~h}$ at $37^{\circ} \mathrm{C}$. For signal conversion, slides were incubated with $50 \mu \mathrm{l}$ of converter-POD (according to the manufacturer's instructions) for light microscopic analysis for $30 \mathrm{~min}$ at $37^{\circ} \mathrm{C}$, rinsed with PBS, and then incubated with $50 \mu \mathrm{l}$ of Fast Red substrate solution for $10 \mathrm{~min}$ at $25^{\circ} \mathrm{C}$. The samples were examined and counted for TUNEL-positive cells independently by two of the authors, who had no information about the samples. TUNEL-positive cells and total cell numbers were counted in randomly chosen ten to fifteen fields per case and apoptotic index (AI) was calculated $(\mathrm{AI}=$ apoptotic cells/total cells $\times 100)$.

\section{Caspase-3 activity and protein determination}

Both adherent and floating cells were collected and used for caspase-3 activity. Cells were washed in PBS and lysed with

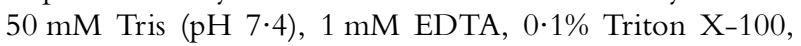

$10 \%$ glycerol, $0 \cdot 5 \%$ sodium deoxycholate, and $0 \cdot 08 \%$ SDS containing $10 \mu \mathrm{g} / \mathrm{ml}$ Protease inhibitor cocktail. The cell lysates were centrifuged at $+4{ }^{\circ} \mathrm{C} 12000 \mathrm{~g}$ for $20 \mathrm{~min}$. The clear supernatants were used for caspase- 3 activity and protein determination. All assays were done in triplicate. Caspase-3 activity was determined using the Enzolyte Homogeneous AMC Caspase-3 Kit from Anaspec, Fremont, CA, USA. Briefly, $150 \mu \mathrm{l}$ of cell lysate was added to wells of a 96-well plate already containing $100 \mathrm{mM}$ HEPES, pH $7 \cdot 4$ and $2 \mathrm{mM}$ dithiothreitol. The reaction was started with the addition of a final concentration of $12.5 \mu \mathrm{M}$ fluorogenic caspase-3
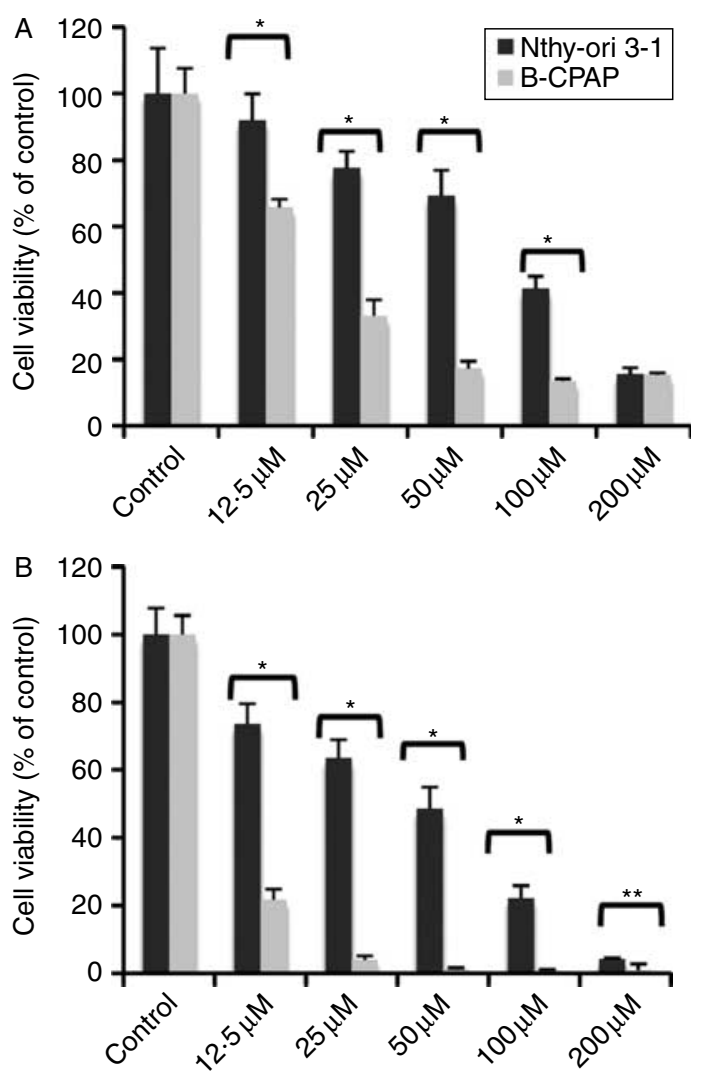

Figure 1 The effect of rosuvastatin on cell viability of normal (Nthyori 3-1) and papillary (B-CPAP) cell lines for, (A) $48 \mathrm{~h}$ and (B) $72 \mathrm{~h}$. Cell viability was assessed by MTT assay. Both thyroid cell lines were treated with various concentrations of rosuvastatin for 48 and $72 \mathrm{~h}$. Rosuvastatin caused a concentration- and time-dependent decrease in the cell viability of both Nthy-ori 3-1 and B-CPAP thyroid cell lines. (A) Nthy-ori 3-1 thyroid cells treated with $12 \cdot 5$, 25,50 , and $100 \mu \mathrm{M}$, concentrations of rosuvastatin for $48 \mathrm{~h}$ show a statistically significant difference compared with B-CPAP thyroid cells treated with the same dose and time interval. (B) Nthy-ori 3-1 thyroid cells treated with all concentrations of rosuvastatin for $72 \mathrm{~h}$ show a statistically significant difference compared with B-CPAP thyroid cells treated with the same dose and time interval. Data are expressed as percentage of cell viability with respect to control. Each column represents the mean \pm S.E.M. of three replicates of two separate experiments $\left({ }^{*} P<0 \cdot 001,{ }^{* *} P<0 \cdot 05\right)$. 
substrate Ac-DEVD-4-methyl-coumaryl-7-amide (AMC). To confirm that enzyme activity was related to caspase-3, parallel samples were incubated for $25 \mathrm{~min}$ with the competitive inhibitor z-DEVD-FMK (final $40 \mu \mathrm{M}$ ) before addition of the substrate. Activity was measured as fluorescence (excitation 354-emission $442 \mathrm{~nm}$ ) after $1 \mathrm{~h}$ using a SpectraMax M2 spectrophotometric plate reader and SOFTmax Pro 3.1.1 software (Molecular Devices, San Diego, CA, USA). Caspase-3 activity was calculated from the slope as fluorescence units per milligram of protein per minute of reaction time as a difference between substrate utilisation velocity in the samples with and without caspase-3 inhibitor, and converted to picomoles of substrate cleaved per milligram of protein per hour based on a standard curve for AMC. Protein concentration in the supernatant was determined by the BCA assay. Enzyme activity is expressed as mean \pm s.D.

\section{Statistical analysis}

The Student's two-tailed $t$-test was used to determine the statistical significance of detected differences, and a value of $P<0 \cdot 05$ was considered statistically significant.

\section{Results}

Rosuvastatin decreases proliferation and induces cell death in thyroid cells in a dose- and time-dependent manner

Rosuvastatin caused a concentration- and time-dependent cell injury in both Nthy-ori 3-1 and B-CPAP thyroid cell lines (Fig. 1). Rosuvastatin treatment at 12.5, 25, 50, 100, and $200 \mu \mathrm{M}$ concentrations resulted in decreased cell viability of B-CPAP cells after 48 and $72 \mathrm{~h}$ (66 to $15 \%$ and 22 to $1 \%$ respectively). $\mathrm{IC}_{50}$ values for $\mathrm{B}-\mathrm{CPAP}$ cells for 48 and $72 \mathrm{~h}$ were 12.9 and $4.6 \mu \mathrm{M}$ respectively. Rosuvastatin treatment at the same concentrations resulted in loss of cell viability of Nthy-ori 3-1 cells after 48 and $72 \mathrm{~h}$ (92 to $16 \%$ and 74 to $4 \%$; Fig. $1 \mathrm{~A}$ and B). $\mathrm{IC}_{50}$ values for Nthy-ori 3-1 cells for 48 and $72 \mathrm{~h}$ were 81.4 and $43.9 \mu \mathrm{M}$ respectively. There was a statistically significant difference in the cell viability between Nthy-ori 3-1 cells and B-CPAP cells treated with $12 \cdot 5,25,50$, and $100 \mu \mathrm{M}$ of rosuvastatin at $48 \mathrm{~h}$ $(P<0 \cdot 001, P<0 \cdot 001, P<0 \cdot 001$, and $P<0 \cdot 001$ respectively; Fig. 1A) and $12 \cdot 5,25,50,100$, and $200 \mu \mathrm{M}$ of rosuvastatin at $72 \mathrm{~h}(P<0.001, P<0.001, P<0.001, P<0 \cdot 001$, and $P=0.033$ respectively; Fig. 1B).

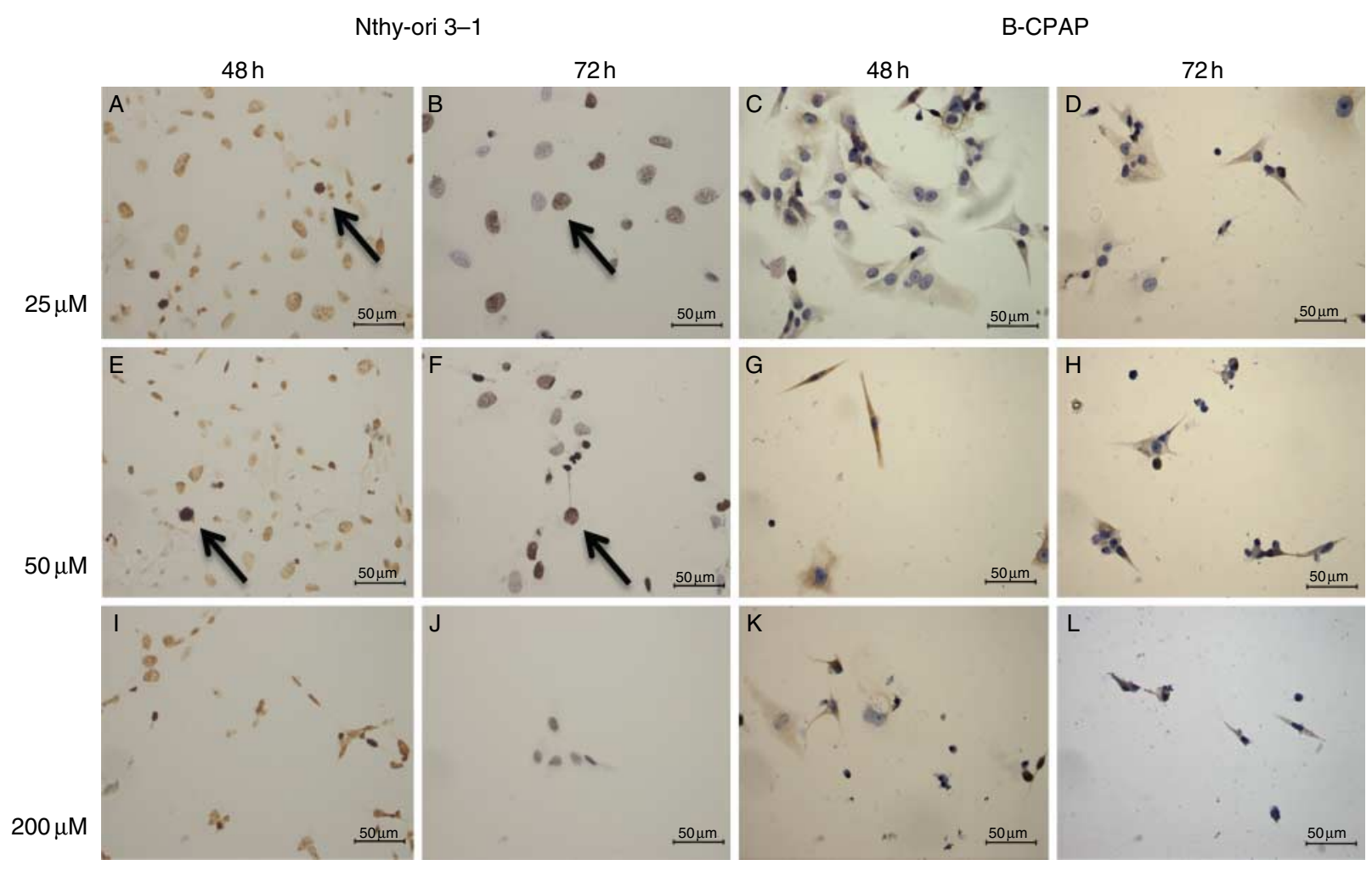

Figure 2 The immune reactivity of Ki-67 on Nthy-ori 3-1 and B-CPAP thyroid cells treated with $25 \mu \mathrm{M}(\mathrm{A}, \mathrm{B}, \mathrm{C}$, and D), $50 \mu \mathrm{M}(\mathrm{E}, \mathrm{F}, \mathrm{G}$ and $\mathrm{H}$ ) and $200 \mu \mathrm{M}(\mathrm{I}, \mathrm{J}, \mathrm{K}$, and L) rosuvastatin after 48 and $72 \mathrm{~h}$. Arrows indicate Ki-67 positive cells with brown nucleus (indirect immunoperoxidase, hematoxylin $\times 400$ ). Full colour version of this figure available via http://dx.doi.org/10.1530/JOE-10-0411. 
Both Nthy-ori 3-1 and B-CPAP thyroid cell lines grown on coverslips showed a spindle shape and an epitheloid morphology in light microscopy. Ki-67 immune-reactive cells in both untreated Nthy-ori 3-1 and B-CPAP thyroid cell lines were observed. There was no statistically significant difference in the immunoreactivity of $\mathrm{Ki}-67$ between untreated Nthy-ori 3-1 and B-CPAP thyroid cell lines for 48 and $72 \mathrm{~h}(P>0 \cdot 1$ and $P>0 \cdot 1$ respectively). Rosuvastatin treatment at $25,50,100$, and $200 \mu \mathrm{M}$ concentrations resulted in variable degrees of cell detachment, ranging from elongated to epitheloid cells and floating cells. The immunoreactivity of $\mathrm{Ki}-67$ was observed to be moderate to weak in the nucleus of Nthy-ori 3-1 cells with increasing concentrations of rosuvastatin treatment at 48 and $72 \mathrm{~h}$. The immunoreactivity of Ki-67 was detected on Nthy-ori 3-1 cells treated with 25 and $50 \mu \mathrm{M}$ rosuvastatin after 48 and $72 \mathrm{~h}$ in contrast to B-CPAP cells treated with the same dose and the same intervals (Fig. 2A-H). There was a statistically significant difference in the immunoreactivity of Ki-67 between Nthy-ori 3-1 cells and B-CPAP cells treated with $25,50,100$, and $200 \mu \mathrm{M}$ of rosuvastatin at $48 \mathrm{~h}(P=0 \cdot 017$, $P<0 \cdot 001, P=0 \cdot 022$, and $P=0.005$ respectively; Fig. $3 \mathrm{~A})$. Ki-67 showed a weak immunoreactivity on Nthy-ori 3-1 cells treated with $200 \mu \mathrm{M}$ rosuvastatin for 48 and $72 \mathrm{~h}$, while B-CPAP cells showed a weak to negative immunoreactivity of $\mathrm{Ki}-67$ with all concentrations of rosuvastatin at both time intervals except for $25 \mu \mathrm{M}$ concentration at $48 \mathrm{~h}$ treatment (Fig. 2A-L). A statistically significant difference was detected in the immunoreactivity of Ki-67 between Nthy-ori 3-1 cells and B-CPAP cells treated with 25, 50, 100, and $200 \mu \mathrm{M}$ of rosuvastatin at $72 \mathrm{~h}(P<0 \cdot 001, P=0 \cdot 045, P<0 \cdot 001$, and $P=0 \cdot 001$ respectively; Fig. $3 \mathrm{~B})$.

\section{Rosuvastatin induces G1 phase arrest}

Flow cytometry analysis was performed to examine the effects of rosuvastatin on cell cycle. Treatment with increasing concentrations of rosuvastatin in Nthy-ori 3-1 cells led to a dosedependent increase in $\mathrm{S}$ phase $(P<0 \cdot 001, n=2)$. However, the same treatment caused G1 phase arrest in B-CPAP cells (Table 1), with a subG1 cell peak (Fig. 4). According to the cell cycle analysis, $\mathrm{S}$ phase was found to be significantly decreased $(P<0 \cdot 001, n=2)$ in B-CPAP cells (Table 1$)$.

\section{Morphologic changes}

In the light microscopic examination of semithin sections, the nuclei of round cells with prominent nucleolus were observed in both untreated Nthy-ori 3-1 and B-CPAP cell lines. Some of the untreated B-CPAP cells showed vacuoles in their cytoplasm. A gradual decrease in the number of cells in both groups was detected with increasing concentrations and time intervals of rosuvastatin treatment (Fig. 5). The number of B-CPAP cells was decreased substantially compared with Nthy-ori 3-1 cells treated with the same dose and at the same interval. The number of vacuoles was increased in the
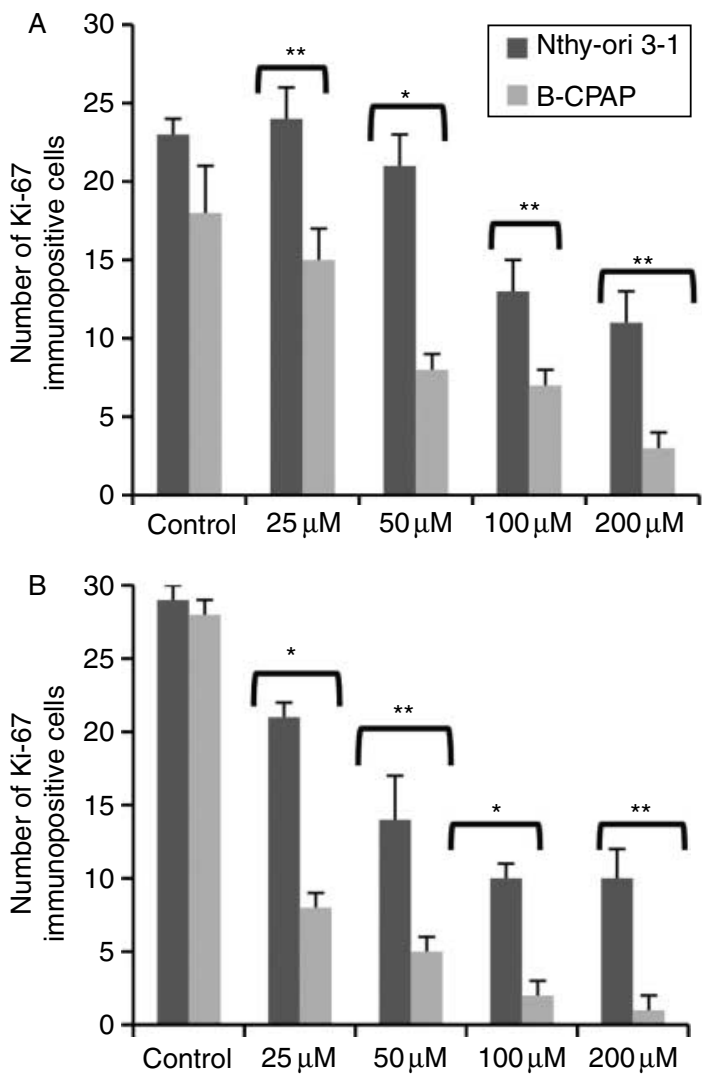

Figure 3 Number of $\mathrm{Ki}-67$ immunopositive Nthy-ori 3-1 and B-CPAP thyroid cells treated with 25, 50, 100, and $200 \mu \mathrm{M}$ rosuvastatin after 48 and $72 \mathrm{~h}$. The number of Ki-67 positive cells was decreased with increasing concentrations of rosuvastatin treatment after (A) $48 \mathrm{~h}$ and (B) $72 \mathrm{~h}$. A significantly higher number of $\mathrm{Ki}-67$ positive Nthy-ori 3-1 thyroid cells were detected with all concentrations of rosuvastatin for 48 and $72 \mathrm{~h}$ compared with $\mathrm{B}-\mathrm{CPAP}$ thyroid cells treated with the same concentration and time interval $\left({ }^{*} P<0 \cdot 001,{ }^{* *} P<0 \cdot 05\right)$.

cytoplasm of B-CPAP cells with increasing concentrations of rosuvastatin and time. Apoptotic cells with condensed nuclei were observed in B-CPAP cells treated with 12·5, 25, 50, 100, and $200 \mu \mathrm{M}$ concentrations of rosuvastatin (Fig. 5K-T). After both 48 and $72 \mathrm{~h}$ treatment periods, cells showing normal morphology were not observed in B-CPAP cells at $200 \mu \mathrm{M}$ concentrations of rosuvastatin treatment (Fig. $5 \mathrm{O}$ and $\mathrm{T}$ ).

In the electron microscopic examination, euchromatic nucleus, prominent nucleolus, and abundant rough-surfaced endoplasmic reticulum, vesicles, and secondary lysosomes in the cytoplasm of both untreated Nthy-ori 3-1 and B-CPAP cells were observed. In untreated B-CPAP cells, the nucleus was enlarged and indented. The ratio of nucleus to cytoplasm was increased. Besides, B-CPAP cells contained more mitochondria around the nucleus compared with that of Nthy-ori 3-1 cells.

Nthy-ori 3-1 cells treated with $12 \cdot 5$ and $25 \mu \mathrm{M}$ rosuvastatin for $48 \mathrm{~h}$ showed no significant ultrastructural alterations compared with untreated Nthy-ori 3-1 cells. B-CPAP cells treated with $12 \cdot 5$ and $25 \mu \mathrm{M}$ rosuvastatin for $48 \mathrm{~h}$ showed an 


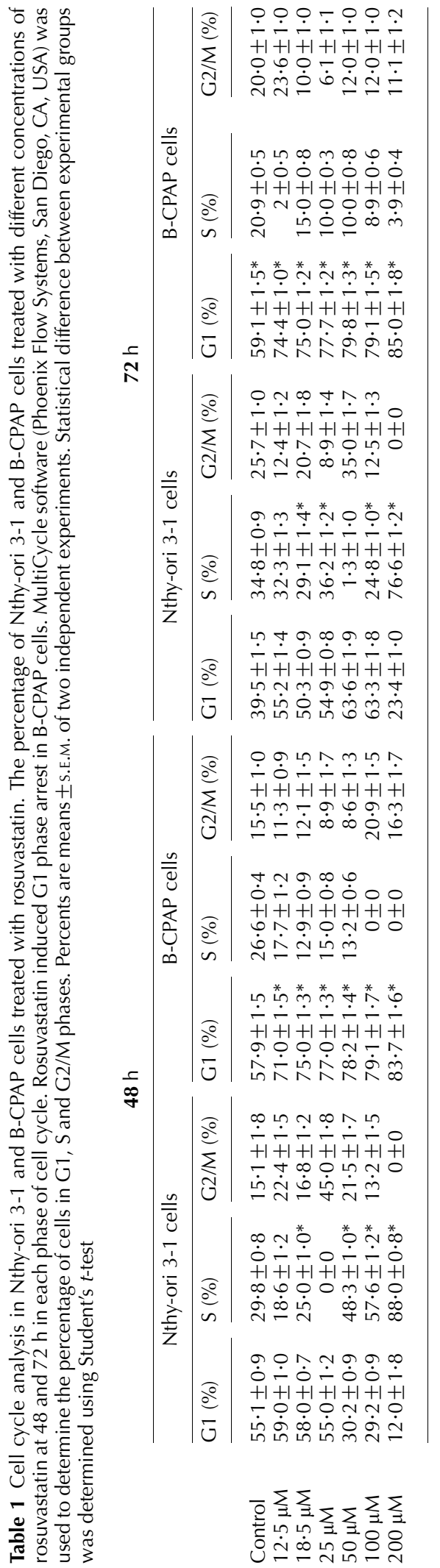

Journal of Endocrinology (2011) 210, 105-115 increase in the number of cytoplasmic vacuoles and lipid droplets. Apoptotic cells with condensed nucleus were observed among these cells with $25 \mu \mathrm{M}$ rosuvastatin concentration (Fig. 6A-D). At $50 \mu \mathrm{M}$ concentration of rosuvastatin treatment after $48 \mathrm{~h}$, Nthy-ori 3-1 cells showed some vacuolisation in their cytoplasm and enlarged rough endoplasmic reticulum cisterna was seen filled with a moderate electron-dense material (Fig. 6E). At the same concentration and same time intervals, B-CPAP cells were almost completely filled with vacuoles, which tended to fuse with each other to form larger vacuoles. Most of the B-CPAP cells completely lost their cell membrane and the cytoplasmic content was extremely degenerated. The widening of perinuclear cisterna and phagocytic vacuoles filled with membranous residues was evident and some cells showing apoptosis with condensed nucleus were also encountered (Fig. 6F). The cytoplasm was filled with enlarged pleomorphic vacuoles, but the nucleus and nucleolus was intact and the integrity of the cells was not disturbed in most of the Nthy-ori 3-1 cells treated with $100 \mu \mathrm{M}$ rosuvastatin for $48 \mathrm{~h}$ (Fig. 6G). B-CPAP cells at the same concentration and time interval showed condensation of the nuclear material and formation of the apoptotic bodies (Fig. $6 \mathrm{H}$ ). At $200 \mu \mathrm{M}$, rosuvastatin treatment after $48 \mathrm{~h}$, Nthy-ori 3-1 cells showed intense vacuolisation and the vacuoles were seen either filled with moderate electron-dense material or membranous residues (Fig. 6I). In B-CPAP cells, disintegration of the cells showing the whole morphology of the apoptotic changes was evident (Fig. 6J).

Both Nthy-ori 3-1 and B-CPAP cells treated with $12 \cdot 5$ and $25 \mu \mathrm{M}$ rosuvastatin for $72 \mathrm{~h}$ showed some small vesicles (Fig. 7A-D). An increase in the number of lipid droplets and vesicles were examined in Nthy-ori 3-1 cells treated with 50 and $100 \mu \mathrm{M}$ concentration of rosuvastatin for $72 \mathrm{~h}$. Most of the B-CPAP cells were degenerated with the same concentration and same time interval (Fig. 7E-H). In $200 \mu \mathrm{M}$ concentration of rosuvastatin for $72 \mathrm{~h}$, Nthy-ori 3-1 cells showed an increased number of lipid droplets and vesicles in their cytoplasm, but still the cells were not disintegrated - the nucleus and cytoplasm of the cells were intact (Fig. 7I). Cell death was prominent in B-CPAP cells treated with 100 and $200 \mu \mathrm{M}$ rosuvastatin for $72 \mathrm{~h}$ (Fig. $7 \mathrm{H}$ and $\mathrm{J}$ ).

The percentage of Nthy-ori 3-1 and B-CPAP cells showing autophagic and apoptotic morphology with different concentrations of rosuvastatin treatment was given in Table 2. The percentage of B-CPAP cells showing autophagy was $44 \%$ with $18.5 \mu \mathrm{M}$ rosuvastatin at $48 \mathrm{~h}$. A decrease in the percentage of cells showing autophagy was determined with increasing concentrations of rosuvastatin in B-CPAP cells. Rosuvastatin treatment at $12 \cdot 5,25,50,100$, and $200 \mu \mathrm{M}$ concentrations increased the percentage of B-CPAP cells showing apoptotic morphology after 48 and $72 \mathrm{~h}(28-98 \%$ and $6-66 \%$ respectively). Rosuvastatin treatment with higher concentrations caused an increase in the percentage of Nthy-ori 3-1 cells with fragmented dark nuclei and/or apoptotic bodies after $72 \mathrm{~h}$. There was a statistically significant difference in the percentage of cells showing apoptosis between Nthy-ori 3-1 

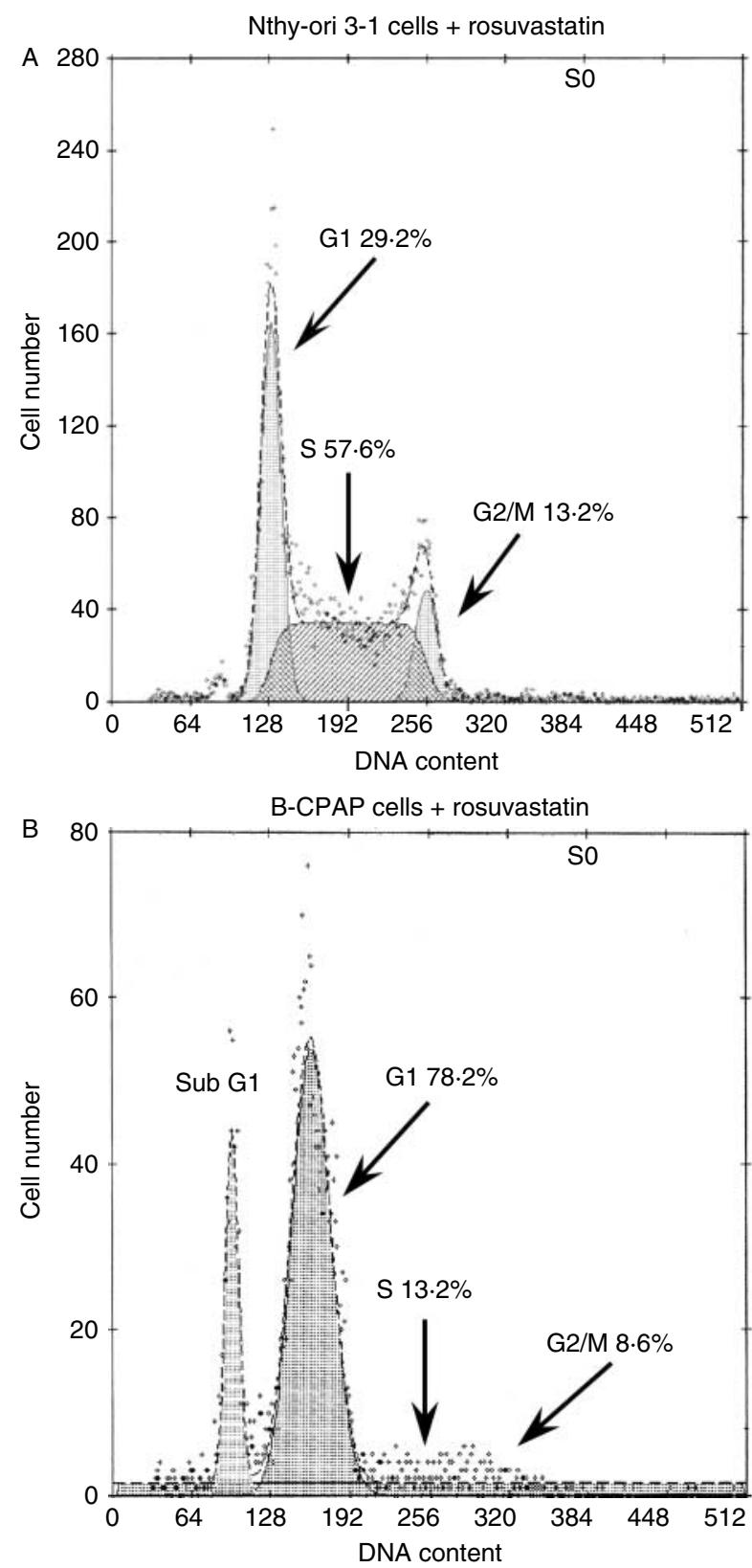

Figure 4 Representative flow cytometry cell cycle histogram. Cell cycle analysis by flow cytometry G1, S, and G2/M phase in Nthy-ori 3-1 thyroid cells treated with $100 \mu \mathrm{M}$ rosuvastatin for $48 \mathrm{~h}$ (A). Cell cycle analysis by flow cytometry G1, S, G2/M phase and SubG1 peak (apoptotic peak) in B-CPAP cells treated with $50 \mu \mathrm{M}$ rosuvastatin for $48 \mathrm{~h}(\mathrm{~B})$. Apoptosis was examined by sub $\mathrm{G} 1$ in $\mathrm{B}-\mathrm{CPAP}$ cells treated with rosuvastatin. MultiCycle software (Phoenix Flow Systems, San Diego, CA, USA) was used to determine the percentage of cells in the cell cycle phases.

cells and B-CPAP cells treated with 12.5, 25, 50, and $100 \mu \mathrm{M}$ of rosuvastatin at $48 \mathrm{~h}(P<0 \cdot 05, P<0 \cdot 001, P<0 \cdot 05$, and $P<0 \cdot 05$ respectively) and $18 \cdot 5,25$, and $50 \mu \mathrm{M}$ of rosuvastatin at $72 \mathrm{~h}(P<0 \cdot 05, P<0 \cdot 001$, and $P<0 \cdot 001$ respectively).
Rosuvastatin induces apoptosis in B-CPAP cells

As a further indication of apoptosis, caspase-3 activity and TUNEL analysis were monitored in both Nthy-ori 3-1 and B-CPAP cells. Rosuvastatin treatment caused a dose- and time-dependent increase in caspase-3 activity in both Nthy-ori 3-1 and B-CPAP cells. The effects of rosuvastatin on caspase-3 activity were significantly higher in B-CPAP cells as opposed to Nthy-ori 3-1 cells at $48 \mathrm{~h}(P=0 \cdot 002)$. This increase was even more significant at $72 \mathrm{~h}$ on B-CPAP cell line $(P=0 \cdot 001)$. In good comparison with $\mathrm{IC}_{50}$ values, B-CPAP cells were found to be more susceptible to caspase-3 activation at lower rosuvastatin concentrations (Fig. 8).

The TUNEL assay also confirmed caspase- 3 activity in both Nthy-ori 3-1 and B-CPAP cells. The AI was found to be 3 and $4 \%$ in untreated Nthy-ori 3-1 and B-CPAP thyroid cells respectively. The number of apoptotic cells was increased with rosuvastatin treatment in both Nthy-ori 3-1 and B-CPAP cells. Rosuvastatin treatment at $12 \cdot 5 \mu \mathrm{M}$ concentration resulted in an increased AI of Nthy-ori 3-1 and B-CPAP cells after $48 \mathrm{~h}$ (6 and 20\% respectively). There was a statistically significant difference in the AI between Nthy-ori 3-1 cells and B-CPAP cells treated with all concentrations of rosuvastatin at $48 \mathrm{~h}$ $(P<0 \cdot 001$; Fig. 9A) and 12.5, 18.5, 25, 50, 100, and $200 \mu \mathrm{M}$ of rosuvastatin at $72 \mathrm{~h}(P<0.001, P<0.001, P<0.05$, $P<0 \cdot 05, P<0 \cdot 05$, and $P<0 \cdot 05$ respectively; Fig. 9B).

\section{Discussion}

Cholesterol, an essential component of cellular membrane, is required for cell proliferation. Statins not only inhibit cholesterol synthesis but also prevent isoprenoid formation and decrease the membrane translocation and activation of the small GTPases and their downstream effectors by inhibiting mevalonate synthesis via blocking HMG-CoA reductase (Alegret \& Silvestre 2006, Katsiki et al. 2009). The effect of statins on cancer cells has been a subject of numerous studies (Zhong et al. 2003, Campbell et al. 2006, Gbelcová et al. 2008). Statins show antineoplastic activity by inhibiting proliferation and activating apoptosis or autophagy in various cancer cell lines (Bifulco et al. 1999, Sassano \& Platanias 2008, Parikh et al. 2010). The effect of rosuvastatin treatment on papillary thyroid cells was investigated and was found that cell death occurred in $34 \%$ of B-CPAP cells with $12.5 \mu \mathrm{M}$ rosuvastatin treatment, whereas this ratio was $8 \%$ for Nthy-ori 3-1 cells at $48 \mathrm{~h}$. Higher doses resulted in an increased loss of cell viability in both cell lines. The immunohistochemical labeling of $\mathrm{Ki}-67$, conducted in parallel with the detection of cell cytotoxicity, revealed that a low concentration $(\geq 25 \mu \mathrm{M})$ of rosuvastatin diminished cell vitality and proliferation in B-CPAP cell line. However, positive immunoreactivity of Ki-67 in Nthy-ori 3-1 cells treated with even higher concentrations of rosuvastatin, indicating preserved cell proliferation, were observed. Also, in these cells, a dosedependent increase in S phase by FACS analysis was found. 
Nthy-ori 3-1

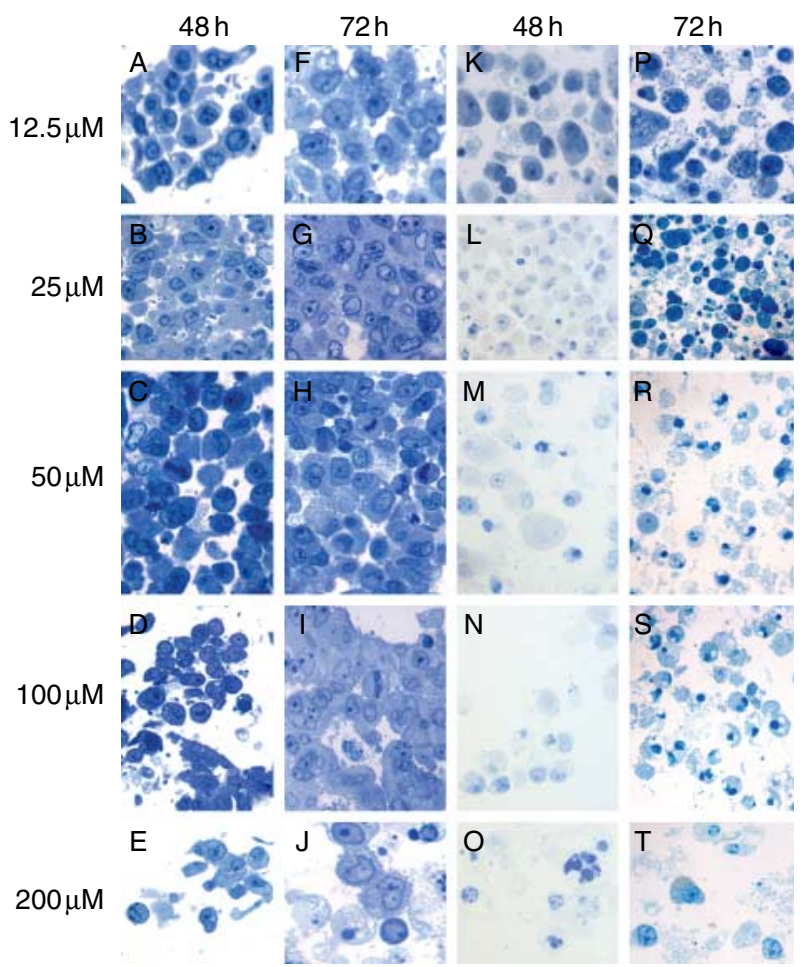

Figure 5 Nthy-ori 3-1 (A-J) and B-CPAP (K-T) thyroid cell lines treated with rosuvastatin for 48 and $72 \mathrm{~h}$. A decrease in the number of cells with normal morphology is seen in both groups with increasing concentrations and time intervals of rosuvastatin treatment (Metilen blue-Azurll $\times 630$ ). Full colour version of this figure available via http://dx.doi.org/10.1530/JOE-10-0411.

Our findings demonstrated that rosuvastatin treatment resulted in more prominent loss of cell proliferation in B-CPAP cells than Nthy-ori 3-1 thyroid cells.

Moreover, the dose-dependent rosuvastatin suppression of B-CPAP cell proliferation was due to the induction of G1 phase arrest and promotion of apoptosis. Caspase-3 activation is one of the earliest indicators of apoptosis (Thornberry \& Lazebnik 1998) and is known to cleave PARP, a DNA repair enzyme (Soldani \& Scovassi 2002, Heeres \& Hergenrother 2007). A similar trend of increase in caspase-3 activity, AI by TUNEL assay and subG1 peak by flow cytometry analysis in B-CPAP cells compared with Nthy-ori 3-1 cells was observed.

Thyroid follicular cells are active cells and have organelles associated with both secretory and absorptive features. Numerous profiles of rough-surfaced endoplasmic reticulum, small vesicles, abundant lysosomes, and endocytotic vesicles were the ultrastructure features of both untreated cell lines, as expected. Accumulation of lipid droplets, lysosomes, vesicles in the cytoplasm, and enlargement of endoplasmic reticulum were the first signs that were detected with rosuvastatin treatment in thyroid cell lines. Enlargement of endoplasmic reticulum was observed in B-CPAP cells even in small doses, whereas enlargement of endoplasmic reticulum occurred in Nthy-ori 3-1 cells in higher doses. HMG-CoAR is an integral endoplasmic reticulum membrane protein. Endoplasmic reticulum is poor in cholesterol and is highly sensitive to cholesterol alterations (Ikonen 2006). Enlargement of endoplasmic reticulum in thyroid cells with rosuvastatin treatment may indicate the response of this organelle to cholesterol alterations induced by rosuvastatin treatment, and B-CPAP cells are more sensitive to cholesterol alterations than Nthy-ori 3-1 cells.

Autophagy is a catabolic process that involves lysosomal degradation and recycling of cytoplasmic constituents. In order to maintain control of cellular components, basal autophagy plays an important role in cellular homeostasis by degrading excessive damaged proteins and organelles

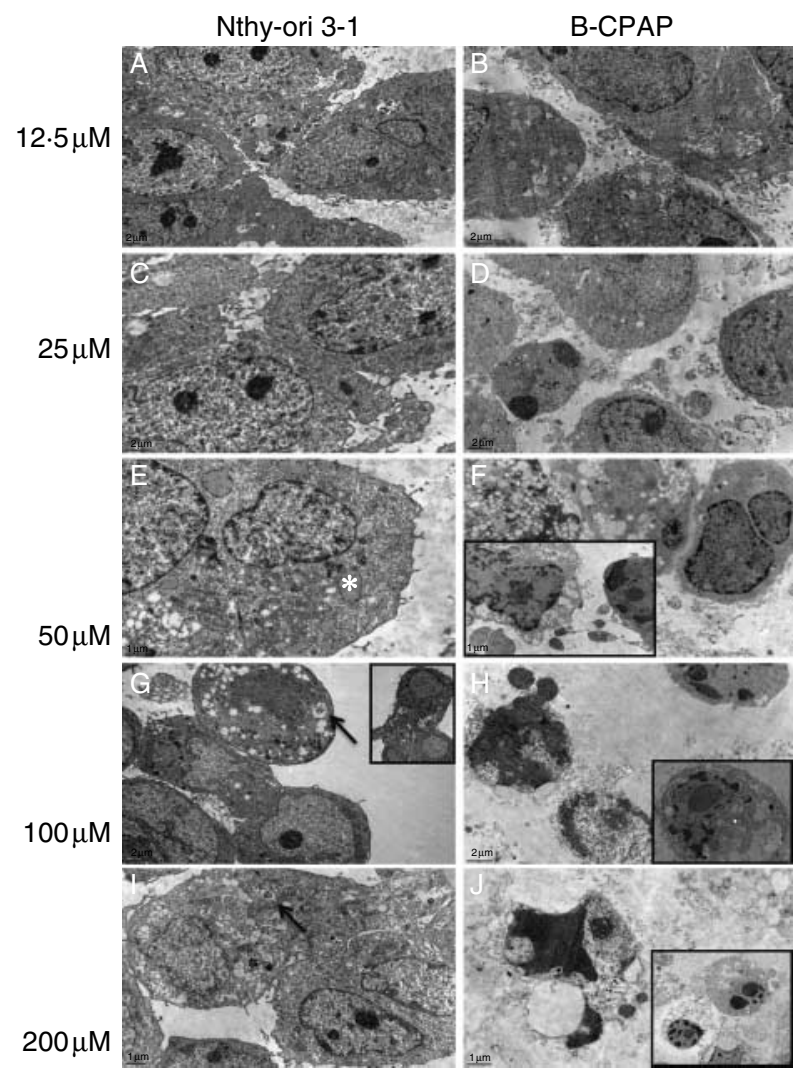

Figure 6 Nthy-ori 3-1 and B-CPAP thyroid cells treated with rosuvastatin for $48 \mathrm{~h}$. Nthy-ori 3-1 thyroid cells treated with (A) $12.5 \mu \mathrm{M},(\mathrm{C}) 25 \mu \mathrm{M}$ (E) $50 \mu \mathrm{M}$ (G) $100 \mu \mathrm{M}$ (I) $200 \mu \mathrm{M}$ rosuvastatin. B-CPAP cells treated with (B) $12 \cdot 5 \mu \mathrm{M}$ (D) $25 \mu \mathrm{M}$ (F) $50 \mu \mathrm{M}(\mathrm{H})$ $100 \mu \mathrm{M}(\mathrm{J}) 200 \mu \mathrm{M}$ rosuvastatin. Increasing numbers of vesicles are seen in the cytoplasm of both thyroid cell lines treated with rosuvastatin. Intense vacuolisation and vesicles containing cytoplasmic material and/or membrane residues (arrow) are seen with increasing concentrations of rosuvastatin in Nthy-ori 3-1 thyroid cells. Enlarged rough endoplasmic reticulum cisterna (asterisks) is seen in $50 \mu \mathrm{M}$ rosuvastatin-treated Nthy-ori 3-1 thyroid cells. The apoptotic cells with condensed nuclei are detected in rosuvastatintreated B-CPAP thyroid cells (Uranyl acetate-lead citrate, A:

$\times 5000 ; B, C, D, F, G$ inset, H: $\times 8000 ; E, I, F$ inset: $\times 12000$; $\mathrm{H}$ inset, J: 15 000; J inset: $\times 6000)$. 


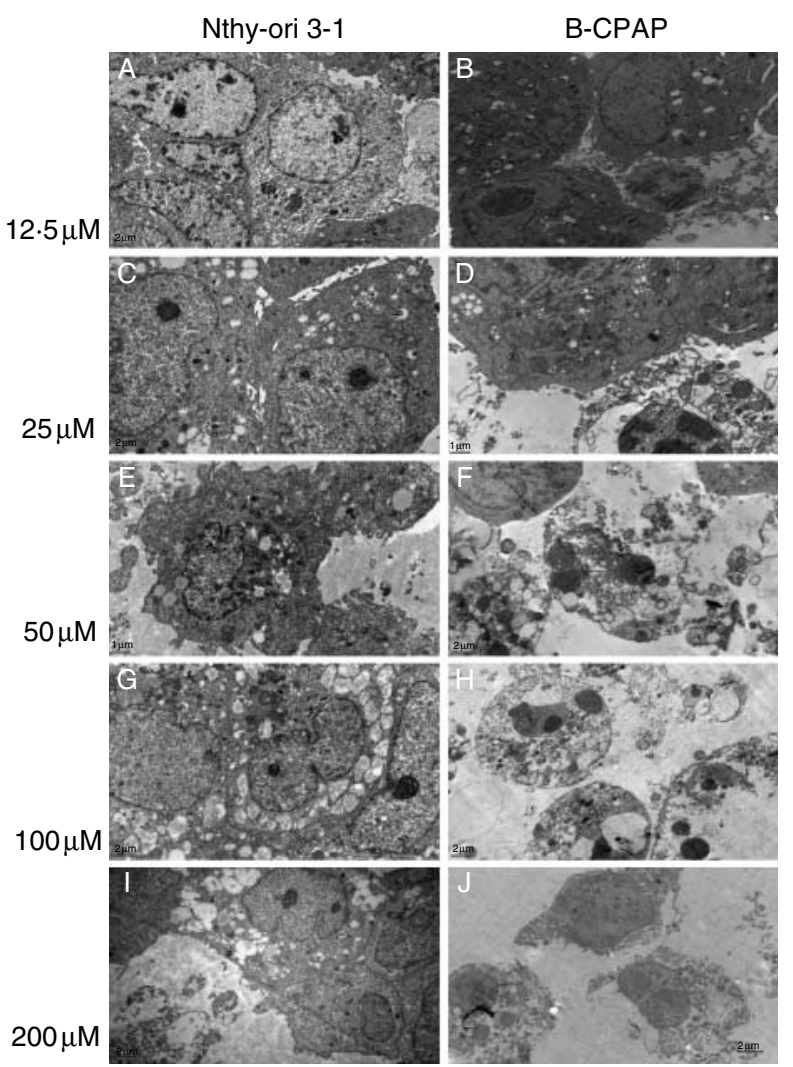

Figure 7 Nthy-ori 3-1 and B-CPAP thyroid cells treated with rosuvastatin for $72 \mathrm{~h}$. Nthy-ori 3-1 thyroid cells treated with (A) $12.5 \mu \mathrm{M}$ (C) $25 \mu \mathrm{M}$ (E) $50 \mu \mathrm{M}$ (G) $100 \mu \mathrm{M}$ (I) $200 \mu \mathrm{M}$ rosuvastatin. B-CPAP cells treated with (B) $12.5 \mu \mathrm{M}$ (D) $25 \mu \mathrm{M}$ (F) $50 \mu \mathrm{M}(\mathrm{H})$ $100 \mu \mathrm{M}$ (J) $200 \mu \mathrm{M}$ rosuvastatin. (A and D) An increase in the number of secondary lysosomes and autophagosomes is observed with 12.5 and $25 \mu \mathrm{M}$ concentrations of rosuvastatin. (E, G, and I) Lipid droplets and vesicles are examined in Nthy-ori 3-1 cells. $(\mathrm{F}, \mathrm{H}$, and J) B-CPAP cells were degenerated (Uranyl acetate-lead citrate A, B, D, E, G, H: $\times 8000$; C: $\times 12$ 000; F: ×6000).

(Thorburn 2008). Endoplasmic reticulum stress and induction of the unfolded protein response (UPR) pathways stimulate autophagy in mammalian cells (Hoyer-Hansen \& Jaattela 2007, Yorimitsu et al. 2006). It has been demonstrated that statin treatment causes the induction of the UPR (Chen et al. 2008, Mörck et al. 2009). Enlargement of perinuclear cisterna in thyroid cells, which may be an ultrastructural feature of stress caused by rosuvastatin treatment, was observed. In the present study, B-CPAP cells showed an intense vacuolisation and engulfment of cytoplasm and/or membrane residues by autophagic vesicles, which are the hallmarks of autophagy, with low concentrations and $48 \mathrm{~h}$ incubations. Nthy-ori 3-1 cells showed these autophagic changes with higher concentrations. Although autophagy is a pro-survival defense mechanism of cells to stress, there is also evidence that over-stimulation of autophagy can lead to cell death, by activating apoptosis (Scott et al. 2007) or autophagic cell death (Levine \& Yuan 2005, Tsujimoto \& Shimizu 2005,
$\stackrel{\vartheta}{F}$

¿

$\stackrel{1}{N}$

宅

$\stackrel{\infty}{+}$

范

घ

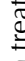

空

究

to

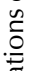

苋

ठ

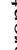

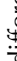



3

응

है

\section{음}

흥

\section{.}

든.

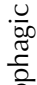

壳

依

足

竞竞 $\frac{\pi}{0}$

나용

它

랑

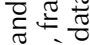

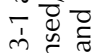

등 훙 능

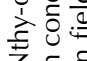

Z

03 엉

要

원 응

ब。

兵䏠.

N

응

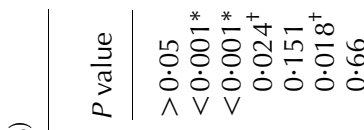

$\stackrel{-a}{\varrho}$

$\stackrel{0}{\overline{0}}$

.

$\frac{a}{2}=$

责

$\frac{10}{3}$

$\frac{1}{N}$

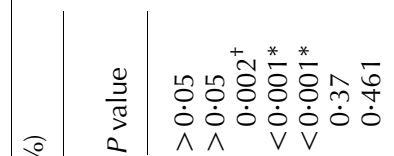

อ

胥

는

응

\&

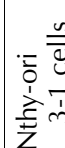

৪৪৪ㅇ ஸे

$\dot{\sim} \dot{n} \dot{-} \dot{0} \dot{\sim} \dot{-}$ $+1+1+1+1+1+1+$

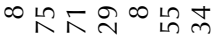

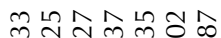
$\dot{0} \dot{0} \dot{0} \dot{m} \dot{\sim} \dot{0}$ $+1+1+1+1+1+1+1$ $+\infty \sigma= \pm \infty \sigma$

2

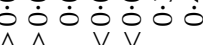

m৪৪৪ ஸे $\dot{0} \dot{\sim} \dot{\circ} \dot{\circ} \dot{-} \dot{T}$ $+1+1+1+1+1+1+1$ +

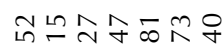
$\dot{0} \dot{0} \dot{0} \dot{0} \dot{0} \dot{\dot{\theta}}$ 1
$+1+1+1+1+1+1+1$ nOLn

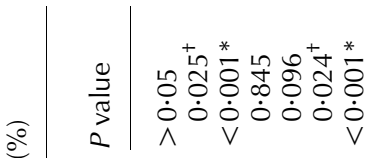

व $a$

$\stackrel{\square}{\overline{\mathcal{U}}}$

$\frac{0}{20}$

这告

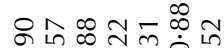
ن் $\dot{0} \dot{\dot{m}} \dot{x}$ 음 $+1+1+1+1+1+1+1$ $\infty$ 어 $\wedge \infty \infty m$

灾

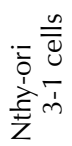

市

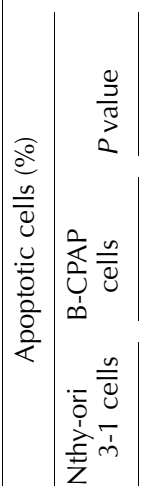

ทำํำ8 $\dot{0} \dot{-} \dot{0} \ddot{\infty} \dot{-}$ $+1+1+1+1+1+1+1$

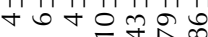

$\frac{\sqrt{2}}{\frac{2}{2}}$

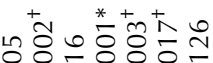
$\dot{0} \dot{0} \dot{0} \dot{0} \dot{0} \dot{0} \dot{0}$

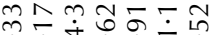

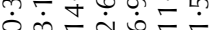
$+1+1+1+1+1 \mp \mp$

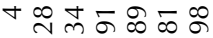

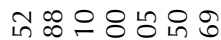
$\dot{0} \dot{0} \dot{\sim} \dot{\sim} \dot{\sim} \dot{\sim} \dot{T}$ $+1+1+1+1+1+1+1$ 

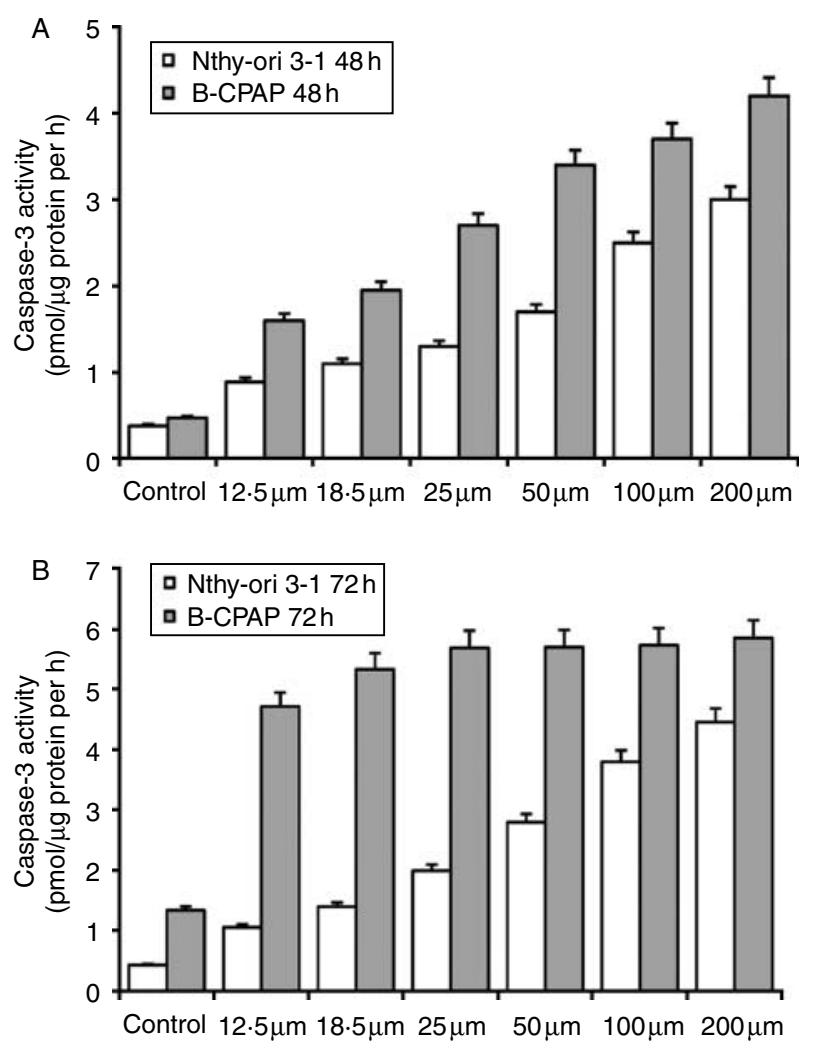

Figure 8 Caspase-3 activity in Nthy-ori 3-1 and B-CPAP thyroid cells treated with increasing rosuvastatin concentrations at (A) $48 \mathrm{~h}$ and (B) 72 h. Rosuvastatin caused a concentration- and timedependent increase in caspase-3 activity of both Nthy-ori 3-1 and B-CPAP thyroid cell lines. Nthy-ori 3-1 thyroid cells treated with all concentrations of rosuvastatin for 48 and $72 \mathrm{~h}$ displayed a statistically significant difference compared with B-CPAP thyroid cells treated with the same dose and time interval $(P \leq 0 \cdot 001)$.

Gozuacik \& Kimchi 2007). It is now believed that there is a crosstalk between apoptosis and autophagy and these processes are different aspects of the same cell death (Thorburn 2008). In this study, with low concentrations of rosuvastatin, B-CPAP cells showed apoptotic features such as nuclear condensation (pyknosis) and fragmentation (karyorrhexis). Moreover, with the highest concentration of rosuvastatin, B-CPAP cells with normal morphology were not detected while Nthy-ori 3-1 cells showed normal morphology with intact nuclei and organelles with the same dose. Our ultrastructural findings support a shift from autophagy to apoptosis with increasing concentrations and time intervals of rosuvastatin treatment in B-CPAP cells.

In this study, various methods such as TUNEL, caspase-3, morphology to determine apoptosis to validate the results were used. TUNEL is a quite sensitive method for detection of in situ DNA fragmentation; however, necrotic cells can be included in apoptotic cell count with this method (Banasiak et al. 2000, Hornsby \& Didenko 2011). Both floating and the adherent cells were evaluated for the morphological assessment, while the TUNEL data demonstrate DNA strand breaks of the adherent cells only. The morphological determination of both floating and the adherent cells may result in higher apoptotic percentages. However, the overall analytic data demonstrated the presence of apoptotic effect of rosuvastatin on thyroid cells in vitro.

This report is the first, to our knowledge, to investigate the effect of rosuvastatin treatment on papillary thyroid cell line. Rosuvastatin induced autophagic changes in B-CPAP cells even in lower doses and a shift from autophagic changes to apoptosis was observed with increasing concentrations of rosuvastatin. In Nthy-ori 3-1 cells, however, baseline/minimal autophagic changes were seen only in higher doses and increased exposure times. The results indicated that rosuvastatin treatment induced autophagy and subsequent apoptosis in
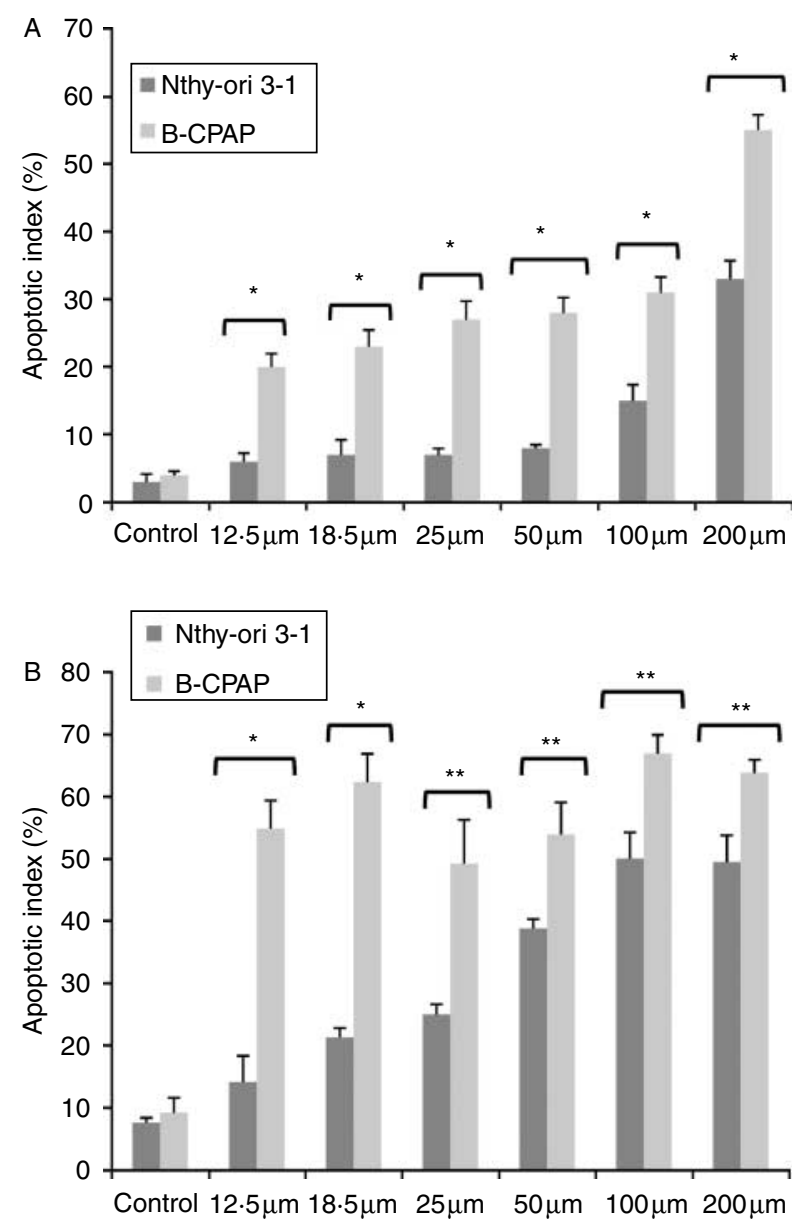

Figure 9 The apoptotic index in Nthy-ori 3-1 and B-CPAP thyroid cells treated with $12 \cdot 5,18 \cdot 5,25,50,100$, and $200 \mu \mathrm{M}$ rosuvastatin after 48 and $72 \mathrm{~h}$. The number of TUNEL-positive apoptotic cells was increased with increasing concentrations of rosuvastatin treatment after (A) $48 \mathrm{~h}$ and $(\mathrm{B}) 72 \mathrm{~h}$. The apoptotic index is significantly increased in B-CPAP thyroid cells with all concentrations of rosuvastatin for 48 and 72 h compared with Nthy-ori 3-1 thyroid cells treated with the same concentration and time interval. The data were given as mean \pm S.E.M. $\left({ }^{*} P<0 \cdot 001,{ }^{* *} P<0 \cdot 05\right)$. 
B-CPAP cells. The present study revealed that rosuvastatin treatment may be an alternative treatment in patients with papillary thyroid cancer, who are refractory to surgery and radioactive iodine ablation. Clinical implications of these findings need to be confirmed by in vivo studies.

\section{Declaration of interest}

The authors declare that there is no conflict of interest that could be perceived as prejudicing the impartiality of the research reported.

\section{Funding}

This research did not receive any specific grant from any funding agency in the public, commercial, or not-for-profit sector.

\section{Acknowledgements}

The authors express their thanks to Omer Ugur, Hacettepe University Faculty of Medicine, Department of Nuclear Medicine. The cell lines were provided from his project supported by a grant from the Turkish Academy of Science Fund no. SBAG-2771 and OU/TUBA GEBIP- 2003-16.

\section{References}

Alegret M \& Silvestre JS 2006 Pleiotropic effects of statins and related pharmacological experimental approaches. Methods and findings in experimental and clinical pharmacology 28 627-656. (doi:10.1358/mf.2006.28. 9.1003573)

Banasiak KJ, Xia Y \& Haddad GG 2000 Mechanisms underlying hypoxiainduced neuronal apoptosis. Progress in Neurobiology 62 215-249. (doi:10.1016/S0301-0082(00)00011-3)

Bifulco M 2008 Therapeutic potential of statins in thyroid proliferative disease. Nature Clinical Practice. Endocrinology and Metabolism 4 242-243. (doi:10.1038/ncpendmet0782)

Bifulco M, Laezza C \& Aloj SM 1999 Inhibition of farnesylation blocks growth but not differentiation in FRTL-5 thyroid cells. Biochimie $\mathbf{8 1}$ 287-290. (doi:10.1016/S0300-9084(99)80072-8)

Campbell MJ, Esserman LJ, Zhou Y, Shoemaker M, Lobo M, Borman E, Baehner F, Kumar AS, Adduci K, Marx C et al. 2006 Breast cancer growth prevention by statins. Cancer Research 66 8707-8714. (doi:10.1158/00085472.CAN-05-4061)

Cappelli C, Castellano M, Pirola I, Martino E, Gandossi E, Delbarba A, Salvi A \& Rosei EA 2008 Reduced thyroid volume and nodularity in dyslipidemic patients on statin treatment. Clinical Endocrinology 68 16-21. (doi:10.1111/j.1365-2265.2007.02982.x)

Chen JC, Wu ML, Huang KC \& Lin WW 2008 HMG-CoA reductase inhibitors activate the unfolded protein response and induce cytoprotective GRP78 expression. Cardiovascular Research 80 138-150. (doi:10.1093/cvr/cvn160)

Gbelcová H, Lenícek M, Zelenka J, Knejzlík Z, Dvoráková G, Zadinová M, Poucková P, Kudla M, Balaz P, Ruml Tet al. 2008 Differences in antitumor effects of various statins on human pancreatic cancer. International Journal of Cancer 122 1214-1221. (doi:10.1002/ijc.23242)

Goldstein JL \& Brown MS 1990 Regulation of the mevalonate pathway. Nature 343 425-430. (doi:10.1038/343425a0)

Gozuacik D \& Kimchi A 2007 Autophagy and cell death. Current Topics in Developmental Biology 78 217-245. (doi:10.1016/S0070-2153(06)78006-1)

Hawk MA, Cesen KT, Siglin JC, Stoner GD \& Ruch RJ 1996 Inhibition of lung tumor cell growth in vitro and mouse lung tumor formation by lovastatin. Cancer Letters 109 217-222. (doi:10.1016/S0304-3835(96)04465-5)
Heeres JT \& Hergenrother PJ 2007 Poly(ADP-ribose) makes a date with death. Current Opinion in Chemical Biology 11 644-653. (doi:10.1016/ j.cbpa.2007.08.038)

Hornsby PJ \& Didenko VV 2011 In situ ligation: a decade and a half of experience. Methods in Molecular Biology 682 49-63. (doi:10.1007/978-160327-409-8_5)

Hoyer-Hansen M \& Jaattela M 2007 Connecting endoplasmic reticulum stress to autophagy by unfolded protein response and calcium. Cell Death and Differentiation 14 1576-1582. (doi:10.1038/sj.cdd.4402200)

Ikonen E 2006 Mechanisms for cellular cholesterol transport: defects and human disease. Physiological Reviews 86 1237-1261. (doi:10.1152/physrev. 00022.2005)

Katsiki N, Tziomalos K, Chatzizisis Y, Elisaf M \& Hatzitolos AI 2009 Effect of HMG-CoA reductase inhibitors on vascular cell apoptosis: beneficial or detrimental? Atherosclerosis 211 9-14. (doi:10.1016/j.atherosclerosis.2009.12.028)

Kawata S, Nagase T, Yamasaki E, Ishiguro H \& Matsuzawa Y 1994 Modulation of the mevalonate pathway and cell growth by pravastatin and d-limonene in a human hepatoma cell line (Hep G2). British Journal of Cancer 69 1015-1020. (doi:10.1038/bjc.1994.199)

Levine B \& Yuan J 2005 Autophagy in cell death: an innocent convict? Journal of Clinical Investigation 115 2679-2688. (doi:10.1172/JCI26390)

Lin YC, Lin JH, Chou CW, Chang YF, Yeh SH \& Chen CC 2008 Statins increase $\mathrm{p} 21$ through inhibition of histone deacetylase activity and release of promoter-associated HDAC1/2. Cancer Research 68 2375-2383. (doi:10. 1158/0008-5472.CAN-07-5807)

Mörck C, Olsen L, Kurth C, Persson A, Storm NJ, Svensson E, Jansson JO, Hellqvist M, Enejder A, Faergeman NJ et al. 2009 Statins inhibit protein lipidation and induce the unfolded protein response in the non-sterol producing nematode Caenorhabditis elegans. PNAS 106 18285-18290. (doi:10.1073/pnas.0907117106)

Parikh A, Childress C, Deitrick K, Lin Q, Rukstalis D \& Yang W 2010 Statininduced autophagy by inhibition of geranylgeranyl biosynthesis in prostate cancer PC3 cells. Prostate 70 971-981. (doi:10.1002/pros.21131)

Sassano A \& Platanias LC 2008 Statins in tumor suppression. Cancer Letters 260 11-19. (doi:10.1016/j.canlet.2007.11.036)

Scott RC, Juhász G \& Neufeld TP 2007 Direct induction of autophagy by Atg1 inhibits cell growth and induces apoptotic cell death. Current Biology 17 1-11. (doi:10.1016/j.cub.2006.10.053)

Sivaprasad U, Abbas T \& Dutta A 2006 Differential efficacy of 3-hydroxy-3methyl glutaryl CoA reductase inhibitors on the cell cycle of prostate cancer cells. Molecular Cancer Therapeutics 5 2310-2316. (doi:10.1158/1535-7163. MCT-06-0175)

Soldani C \& Scovassi I 2002 Poly(ADP-ribose) polymerase-1 cleavage during apoptosis: an update. Apoptosis 7 321-328. (doi:10.1023/ A:1016119328968)

Thorburn A 2008 Apoptosis and autophagy: regulatory connections between two supposedly different processes. Apoptosis 13 1-9. (doi:10.1007/s10495007-0154-9)

Thornberry NA \& Lazebnik Y 1998 Caspases: enemies within. Science 281 1312-1316. (doi:10.1126/science.281.5381.1312)

Tsujimoto Y \& Shimizu S 2005 Another way to die: autophagic programmed cell death. Cell Death and Differentiation 12 1528-1534. (doi:10.1038/sj.cdd. 4401777)

Yorimitsu T, Nair U, Yang Z \& Klionsky DJ 2006 Endoplasmic reticulum stress triggers autophagy. The Journal of Biological Chemistry 281 30299-30304. (doi:10.1074/jbc.M607007200)

Zhong W, Wang C, Chang T \& Lee W 2003 Lovastatin induces apoptosis of anaplastic thyroid cancer cells via inhibitor of protein geranylgeranylation and de novo protein synthesis. Endocrinology 144 3852-3859. (doi:10.1210/ en.2003-0098)

Received in final form 1 April 2011

Accepted 8 April 2011

Made available online as an Accepted Preprint 8 April 2011 